\title{
From Divine Action to Divine Presence: The Next Step in an Integrated Cosmology of Science and Theology
}

\author{
Robert Brodrick* \\ Boston College
}

This paper advances the claim that the perceived rift between theology and scientific cosmology is not merely due to the advances of modern science but also to particular philosophical and theological developments in the realms of epistemology and the social imaginary. In light of this perspective, the author suggests that the recent work done regarding scientific perspectives on divine action represents a first step in progressing scientific and theological insights toward a contemporary integrated cosmology. Non-interventionist notions of God's special action in the world have developed an understanding in which it is possible to uphold traditional theological doctrines without violating the scientific laws of nature. Some theorists working along these lines have assessed the important Christian reality of the resurrection of Jesus Christ as a particular instance of God's special action-the author suggests that it is necessary to build on this idea by moving from a theory of divine action to a theory of divine presence. The issue of divine presence is complicated within the Christian faith by the doctrine of the Ascension, which recognizes the genuine absence of the person of Jesus Christ. The Eucharist (and therefore the Church) is suggested as a necessary topic in further discussion. The solution outlined is that the Eucharist is the continuation of the special divine act of new creation ex vetere (out of the 'old' creation) that was inaugurated in the Resurrection. In this way, the notion of divine presence may be understood in a manner that is both scientifically and humanly meaningful.

\footnotetext{
* Robert Brodrick is a PhD student in the Theology Department at Boston College. His primary focus is in systematic theology with a special interest in ecclesiology and questions regarding the Church's ability to read and respond to the signs of the times.
} 


\section{Introduction: The Necessity of an Integrated Cosmology}

In her 1996 presidential address to the Catholic Theological Society of America, Elizabeth Johnson convincingly articulated how "the endeavor of pre-modern theologians to interpret the whole world in the light of Christian faith gave vitality to their work and inspired impressive systems in which cosmology, anthropology, and theology of God formed a harmonious unity." ${ }^{1}$ This integrated vision contrasts sharply with the contemporary theological arena, in which the first of these three fields, cosmology, is largely missing. Thankfully, the concern over theological cosmology has grown significantly in recent years.

Arthur Peacocke has insisted that "any affirmations about God's relation to the world, any doctrine of creation, if it is not to become vacuous and sterile, must be about the relation of God to, the creation by God of, the world which the natural sciences describe. It seems to me that this is not a situation where Christian, or indeed any, theology has any choice." ${ }^{2}$ Failing to integrate cosmology and theology, following Nancey Murphy, "has resulted in the marginalization of the doctrine [of creation, and therefore also cosmology] both in systematic theology and in the life of the church," while in the second place, "it has left many contemporary Christians without adequate guidance for relating to nature."3

This paper will treat cosmology as a subject properly consisting of both the natural sciences and theology. In the pre-modern era, these disciplines were commonly understood to be related, although advances in the natural sciences were often overshadowed or even hindered by (frequently faulty) metaphysical or theological concerns and assumptions. The tremendous development of scientific method and knowledge from the seventeenth century on has certainly changed this state of affairs.

In our contemporary situation, cosmology is commonly approached from an apparently "flattened" perspective that treats the subject almost exclusively in relation to the natural sciences Here, it is important to note that the common approach is only apparently flattened, for cosmology never formally exists without including metaphysical and theological assumptions and viewpoints. One may be inattentive to these assumptions or claim that by adhering to some form of dualism, agnosticism, or atheism that these assumptions are irrelevant or nonexistent, but one's naïveté about the subject does nothing to change the actual state of affairs.

Although cosmology may remain formally integrated, its apparent flattening has done much damage both to systematic theology and to the life of the Church. In the first place, it has left theology without a framework that incorporates the insights derived by the natural sciences and thus marginalized systematic theology from both academic discourse and the lived life of the

\footnotetext{
${ }^{1}$ Elizabeth Johnson, "Turn to the Heavens and the Earth: Retrieval of the Cosmos in Theology," in Proceedings from the Catholic Theological Society of America 51 (June, 1996): 2.

${ }^{2}$ Arthur Peacocke, Creation and the World of Science (Oxford: Clarendon, 1979), 46.

${ }^{3}$ Nancey Murphy, "Scientific Cosmology: A New Challenge to Theology," in International Symposium on Astrophysics Research and on the Dialogue between Science and Religion, eds. Chris Impey and Catherine Petry (Vatican City State: Vatican Press, 2003), 76.
} 
Church, which is increasingly informed by these sciences. ${ }^{4}$ In order to construct a robust, integrated cosmology that successfully incorporates a creative mutual interaction ${ }^{5}$ of the natural sciences and theology we must first come to grips with the historical process that led to the apparent flattening of cosmology.

The second part of this paper explores recent advances related to scientific perspectives on divine action. These theories make it possible to conceive of traditional theological doctrines without violating the scientific laws of nature. Furthermore, they have made a special effort to direct attention towards the special divine act of the Resurrection. In doing so, divine action theories account not only for the possibility of God's ongoing work of creation in the world, but also give an intelligibility to the real circumstances of such creation. While the contributions of divine action theories provide a wealth of resources for an integrated cosmology, they do not yet address the concern of how to understand the order of the cosmos as a humanly meaningful one.

Thus, in the final section of this paper, I will promote the necessity of adding a theory of divine presence to the conversation between scientific and theological perspectives on cosmology. Christian faith recognizes the difficulty of the issue of divine presence through the doctrine of the Ascension and the Eucharist. On one hand, the Ascension represents the manner in which there exists a genuine absence of the person of Jesus Christ. On the other hand, the Eucharist, and therefore also the Church, exists as the continuation of the special divine act of new creation ex vetere (out of the 'old' creation) that was inaugurated with the Resurrection.

\section{The Exclusion of Cosmology from Theology}

Charles Taylor speaks of popular, contemporary 'subtraction stories,' wherein the flattening of cosmology begins with science marching in on the scene from outside: "science gave us [a] 'naturalistic' explanation of the world. And then people began to look for alternatives to God." Europe and the Americas went through revolutions, rebelling against their churches and monarchies alike, and these peoples soon walked away with a sense of morality that both began and ended with new reference points, of which human flourishing is the most predominant. But this narrative ignores the fact that secular society neither began, nor could have began, with science for two reasons. The first is simply that these changes began long before scientists came along to 'refute the Bible.' The second and perhaps more astonishing factor is that the roots of such changes actually lie within particularly Christian motives, including, among others, a new spirituality of death, judgment and the afterlife, increased devotion to the crucified Christ, a growing dissatisfaction with the

\footnotetext{
${ }^{4}$ William Brown, The Ethos of the Cosmos (Grand Rapids: William B. Eerdmans Publishing Company, 1999), 10. W. Schweiker, Responsibility and Christian Ethics (Cambridge: Cambridge University Press, 1995), 38, quoted in Brown, The Ethos of the Cosmos, 11.

${ }^{5}$ Here I am borrowing the phrase 'creative mutual interaction' from physicist and theologian Robert J. Russell, Cosmology: from alpha to omega-the creative mutual interaction of theology and science (Minneapolis: Fortress Press, 2008).

${ }^{6}$ Charles Taylor, A Secular Age (Cambridge : Harvard University Press, 2007), 26.
} 
divide between hierarchy and laity, and a rejection of perceived Church magic. ${ }^{7}$ Thus, Taylor insists that "the new mechanistic science of the seventeenth century wasn't seen as necessarily threatening to God. It was to the enchanted universe and magic. It also began to pose a problem for particular providences. But there were important Christian motives for going the route of disenchantment. Darwin was not even on the horizon in the eighteenth century." 8

Rather, much of the change from pre-modern to modern worldviews occurred within the social imaginary wherein people's perception and knowledge of the world is not necessarily formulated into precise doctrines or systematic formulas. Within the realm of the social imaginary, Taylor observes that the main moral agenda operative in the formation of the modern cosmological imagination is that of "Reform," which "expresses a profound dissatisfaction with the hierarchical equilibrium between lay life and the renunciative vocations", on account of the demand that "everyone be a real, 100 percent Christian." 10 This process of Reform was, however, not a new development of the $16^{\text {th }}$ century Reformation but rather a continuation of what Karl Jaspers' calls the Axial revolution. ${ }^{11}$ This revolution instigated a break in the social embeddedness between religions prior to the first millennium $\mathrm{BC}$ and those that came later (especially in Confucianism, Buddhism, and Platonism). Before the Axial turn, people were embedded in ways of life that (1) involved social relationships that mediated the presence of spirits, forces, and/or powers, (2) related to 'intra-cosmic' sources of influence and meaning that were associated with things of this world, and (3) understood the purposes of the divine to be defined in terms of human flourishing. In Taylor's diagnosis, the Axial religions served to initiate a break with all three of these forms of embeddedness. ${ }^{12}$ Rather than being completed all at once, these breaks were held in certain tensions until the work of Reform sought to bring about their completion.

The particular historical shape of the work of Reform brought with it unintended consequences. While the details of Taylor's narrative are too numerous to retrace here, the end result was that the disembedding process inherent in the work of Reform also served to disengage people from the sources of meaning in society and the cosmos that they understood as constitutive of their identity. Regarding this point, Taylor writes that:

We might say that we moved from living in a cosmos to being included in a universe. I use 'cosmos' for our forebearers' idea of the totality of existence because it contains the sense of ordered whole. It is not that our universe isn't in its own way ordered, but in the cosmos the order of things was a humanly meaningful one. That is, the principle of order

\footnotetext{
${ }^{7}$ Cf. ibid., chapter 1.6 .

8 Ibid., 26.

${ }^{9}$ Ibid., 61 .

${ }^{10}$ Ibid., 774. Taylor distinguishes between the movements of 'Reform' and the Reformation in that the former is operative primarily on the level of the social imaginary rather than in the formulation of particular doctrines or the schism between the various churches. Reform is nevertheless to be understood as a particular historical movement out of which the various Protestant and Catholic Reformations emerged.

${ }^{11}$ See Karl Jaspers'Vom Ursprung und Ziel der Geschichte (Zürich: Artemis, 1949).

${ }^{12}$ Taylor, A Secular Age, $146 \mathrm{ff}$.
} 
in the cosmos was closely related to, often identical with that which gave shape to our lives. ${ }^{13}$

Thus, from one vantage point the work of Reform can be seen as a continuation of the disembedding work of the Axial revolution. But from this additional angle that Taylor portrays, Reform also implies a shift in the way we understand the structure of meaning itself. In the premodern worldview it was generally understood that sources of meaning existed within the fabric of the cosmos as well as in intra-cosmic spirits and forces that could impose meaningful realities onto 'porous' human beings. But as a result of the disembedding work of Reform, people began to conceive of themselves as closed off or 'buffered' from any sources of meaning that were not generated within the sphere of human consciousness itself. ${ }^{14}$ According to this narrative in which our cosmological imagination shifted from identifying our sense of the ordered whole as a 'cosmos' to a 'universe,' the story cannot simply read that modern science has stripped theologians of the ability to participate in cosmological conversations even though it has insisted that theological cosmology become more fluent in relating to mathematical and scientific observation. ${ }^{15}$ Rather, Taylor's narrative insists that the contemporary milieu is immersed in a very particular type of cosmological imagination where sources of human meaning are immanently generated within the sphere of human consciousness rather than embedded within the ordered structure of the cosmos.

Significant in the history of the exclusion of cosmology from theology is the shift in formal metaphysics occasioned by Kant. His effect can be seen in the fact that

the response to modern science that has had the most pervasive effect on mainline theology as a whole, and the doctrine of creation in particular, was the attempt by nineteenth-century liberal theologians to immunize theology from science. These strategies were heavily inspired by the philosopher Immanuel Kant, who made a sharp distinction between the phenomenal world, known to science, and the noumenal world, known by means of moral intuition. God was to be associated only with the noumenal world. $^{16}$

Seen in this light, the Kantian project continued the disembedding process of which Taylor speaks. Complementing the shift in the social imaginary, Kant's philosophy separated the sphere of human meaning and morality from the fabric of the cosmos itself. As one commentator puts the issue: "Not until Kant was moral philosophy able to detach this inner realm from the closed and fully determined causal network of the physical universe."17

It must be noted, however, that Kant's purpose was certainly not to attack authentic belief in God. Rather, it may be understood as a response to the growing difficulty in locating God's

\footnotetext{
13 Ibid., 59-60.

${ }^{14}$ For a detailed explanation of the distinction between and transition from the phase of 'porous selves' to 'buffered selves,' see ibid., $35 \mathrm{ff}$.

${ }^{15}$ In fact, there are certainly scientists of faith, scientifically-minded theologians, and other individuals who have been quite happy to accept the truths of both fields.

${ }^{16}$ Murphy, "Scientific Cosmology," 75.

${ }^{17}$ Louis Dupre. Passage to Modernity: An Essay in the Hermeneutics of Nature and Culture (New Haven: Yale University Press, 1993), 131.
} 
place in a new conception of the universe. The arrival of Deism in the seventeenth century effected a shift from understanding God as continually active in the world to one in which the universe was left to a set of rigid and unchanging laws even if God may have originally set the world in motion. The analogy of a clockmaker and his clock became famous. After this deistic framework was rejected by David Hume, Kant sought out a new approach by constructing "a new metaphysical system which emphasized the mind's role in organizing sense-data through universal categories of intuition and forms of sensibility." 18 Simply put, as it became less and less viable for human persons to be understood as embedded creatures within the rational order of the cosmos, the new metaphysical alternative allowed for a conception of people as engaged agents embodied in the world through their experience of it. Religion, then, became a matter entirely of practical reason based on our sense of moral obligation rather than as an act knowing through pure reason.

Both Reform and the turn to the subject were successful in counteracting the emergence of deism inasmuch as they were able to once again make God relevant to lived human experience. However, they also led to the flattening of cosmology by divorcing theology and cosmology from one another. In their own respective manners, they constructed a particular worldview in which theology is understood as the field of study which deals with the noumenal world accessed by transcendental experiences or a felt awareness of God while cosmology is understood as a study only of the phenomenal world and is therefore exclusively within the domain of the natural sciences. There were many important reasons for taking this road, for the pre-modern world certainly needed to be challenged in its ethical, epistemological, and cosmological presuppositions. However, we have also seen that the flattening of cosmology has led to problems not only in establishing the legitimacy of theological inquiry but furthermore in the ability of theology to formulate patterns of human relations to nature.

\section{Scientific Perspectives on Divine Action: A First Step}

Over the past two decades, there has been an increase in cross-disciplinary attempts to uncover perspectives relating the natural sciences and Christian theology. A relatively small yet intensely productive group of scientists, theologians, and self-identified 'scientist-theologians, 19 have began the difficult work of dialogue between scientific and theological perspectives on the world. Much of this work has centered on the task of understanding how it is possible to conceive of God's action in the world given the advanced scientific knowledge that we have gained over the last few centuries. ${ }^{20}$ Two general approaches that deserve attention are the

\footnotetext{
${ }^{18}$ Russell, Cosmology, 114.

${ }^{19}$ Cf. John Polkinghorne, Scientists as Theologians: A Comparison of the Writings of Ian Barbour, Arthur Peacocke, and John Polkinghorne (London: SPCK, 1996).

${ }^{20}$ Of special note in this regard is the five volume series "Scientific Perspectives on Divine Action: Twenty Years of Challenge and Progress," eds. R.J. Russell, N. Murphy, W. R. Stoeger (Vatican City State: Vatican Observatory Publications; Berkeley, CA: The Center for Theology and the Natural Sciences; Notre Dame, IN: University of Notre Dame Press, 2008).
} 
development of continuous creation theology as well as non-interventionist objective divine action (NIODA). The first of these approaches moves beyond the deistic framework in a new way. Rather than accepting the distinction between the noumenal and phenomenal worlds, continuous creation establishes a framework in which there is a unified cosmos whose entirety was, is, and will be continually created anew by God. The second approach, NIODA, distinguishes between God's general action in the world and God's special action in the world. Establishing the possibility of the latter means of divine action, as I will discuss below, is particularly important for formulating an integrated cosmology.

Combined, these two approaches successfully advocate for the possibility, from a scientific perspective, of conceiving a God who did not merely create the universe and then cease to act, but rather a God who is continually active in the cosmos. But in addition to establishing the possibility of divine action, an integrated cosmology must also be able to intelligibly understand the reality of such action. Within the Christian faith, arguably the most essential reality to be accounted for is the resurrection of Jesus Christ. Thus, the third part of this section will explore how approaching God's action in the Resurrection as a 'first instance of a new law of nature' and as a new creation ex vetere allows for a non-interventionist approach to understanding this reality.

\section{Continuous creation theology}

One of the great advantages of continuous creation theologies has been their enormous success with incorporating scientific insights from virtually every field. Alfred North Whitehead's process theology derives from a distinct mathematical background, while Pierre Teilhard de Chardin's theology of the Cosmic Christ as the Omega Point has clear evolutionary and biological overtones. Physics is the primary point of departure for Ian Barbour, Robert Russell, and Arthur Peacocke. Many more could be named, and although there are certainly a great variety of differences between each respective theological approach, there is also a great deal of convergence. Summarizing these points of convergence, Russell explains that "the notion of creation continua stands for God's continuing involvement with the world. Not only does God relate to creation as a whole but also to every moment, and God's fundamental relation is as creator. Hence God not only creates the world as a whole but every part of it." ${ }^{21}$ Thus, the most essential feature of continuous creation theologies is that the notion of God's creation of the cosmos is not limited to the first moment in which everything that is came into being. Rather, these theologies emphasize the ongoing work of God in calling forth each new being, event, and moment within the cosmos.

The doctrine of continuous creation does nothing to diminish the more well known doctrine of creation ex nihilo by which it may be understood that: "1) the universe had a beginning [and] 2) the universe depends absolutely and at every moment on God for its sheer

\footnotetext{
${ }^{21}$ Russell, Cosmology, 35.
} 
existence." 22 Rather, continuous creation formulations are seen as a further development of creation theology, although whether the doctrine of continuous creation is to be maintained as separate from creation ex nihilo (such as in the writings of Barbour and Peacocke) or as a part of it (as it is with Hefner, Pannenberg, and Moltmann) is yet to be determined. ${ }^{23}$

In either case, it is worth noting that creation continua in its contemporary form adds to classical creation ex nihilo by allowing for evolutionary concerns. In many theologies of creation ex nihilo, God is understood as the preserver of a fixed order of the cosmos after the initial moment of creation. In contrast, contemporary theologies of continuous creation emphasize the ongoing role of God in bringing new forms of creation into being. ${ }^{24}$ The notion of continuing creation is important in establishing a contemporary integrated cosmology because it forges a new path out of the realm of deism. This new path forward does not accept the two-worlds approach in which the notion of God is given sense only within the subjective, noumenal world while the order and continuation of the universe is operative only within the objective, phenomenal world. Rather, continuous creation theology initiated the need to develop a theoretical approach in which there is only one world, continually created by God anew in each moment.

Non-interventionist objective divine action (NIODA)

A second area of important theological research deals with the issue of God's special action in the world. Here, God's special action is typically differentiated from general divine action in which God is understood to be the primary cause, ground of being, or reason for the existence of all that is. Robert Russell states the question of special divine agency as whether or not "we are right to call certain events 'special' because we are actually responding to God's distinctive action in, together with, and through them. This claim can be made even more sharply: Is it the case that, had God not acted in a special way in a given particular event, the event would not have occurred in precisely the way it did?" 25 One concern with this subject is typically the biblical narrative and whether the acts of God described in it are real events of God's doing, but there is also a deeply rooted theological concern about divine autonomy and freedom. The problem at hand is that theologians must be able to provide an account of special divine agency that does not violate the natural sciences in order to preserve the notion of God's action in the world as a free gift. If, on the one hand, theology provides no account of special divine agency, then it has little else to offer than the deistic framework in which the original act of God's creation of the universe is a free act, but any subsequent actions are bound to a general preservation of the laws of natural science. On the other hand, if theology allows for special divine agency to consist in 'miraculous' events which necessarily defy the laws of science, then

${ }^{22}$ Ibid., 113.

${ }^{23}$ Ibid., 35 .

${ }^{24}$ Cf. Wolfhart Pannenberg, An Introduction to Systematic Theology (Grand Rapids: William B. Eerdmans Publishing Company, 1991), 37ff.

${ }^{25}$ Russell, Cosmology, 115-116. 
it will become increasingly obscure to a human population that is ever more convinced of the inviolability of scientific laws.

Regarding the current state of affairs with theories of divine agency, Russell indicates that positions can typically be divided into two broad viewpoints: those which approach divine agency as objective, and those which approach it as subjective. Thus, special providence is to be conceived either "1) as the objective acts of God in nature and history to which we respond, where these acts are understood as divine interventions into the natural and historical world, or 2) as our subjective response to God's acts, where these acts are understood as uniformly the same in all events whether or not we consider them special." ${ }^{26}$ In other words, those that uphold a subjectivist approach frequently merge the events of special divine action with general divine action and locate any differences within the perspective of the observer-God is held as the cause or source of all events.

However, some events evoke or inspire a response from a person or community such that those people come to understand the action as being from God. But those who uphold theories of objective divine action maintain that if God's action in the world is to be understood as objective, then it must be able to be clearly distinguished from a matter of perception where one observer might claim the event to be 'of God' while another says 'mere chance.' These arguments usually side with conservative, literal interpretations of 'miraculous' events both biblical and, frequently, extra-biblical. The term 'miraculous' here is used to indicate events that defy God's general action in the world, understood in terms of physical and biological laws.

What Russell and others have been calling for is a new approach to divine agency through which we can conceive of "special providence as consisting in the objective acts of God in nature and history to which we respond through faith and we can interpret these acts in a noninterventionist manner consistent with the natural sciences." ${ }^{27}$ Non-interventionist objective divine action (NIODA) agrees with conservative objectivist approaches that God is to be understood as a real actor and the cause of extraordinary events in the world, rather than as a mere perspective by which one may choose to describe certain events. However, NIODA differs from the conservative approach in both what these actions are and how they occur. While conservative approaches rely on God intervening in the regular laws of nature though miraculous events, NIODA maintains that God's special action in the world does not function outside God's general action. Now although this theory neither explains nor proves God's action, "what proposals for NIODA are required to do is to specify a certain area or theory in science that describes one possible location or domain where God's direct or basic acts-although ultimately mysterious and unknowable in themselves-result in an objective event effecting the course of nature without intervention." 28 For instance, one such proposal for NIODA builds on the foundational principle of quantum mechanics such that the outcomes of particular events on the ultra-microscopic level are fundamentally probabilistic and, furthermore, that these outcomes can

\footnotetext{
${ }^{26}$ Ibid., 111.

${ }^{27}$ Ibid., 112.

${ }^{28}$ Ibid., 126.
} 
influence outcomes on the macroscopic level in serious ways without violating any scientific laws. ${ }^{29}$ Thus, it is possible to conceive of ways in which God would be able to directly and objectively act in the world in special circumstances without contradicting or intervening in God's general action.

Continuous creation theology and NIODA are important for an integrated cosmology because they provide legitimate theories that describe the action of God within the continually unfolding order of the cosmos in an intelligible way. While continuous creation conceptions seek to articulate how the universe is continually dependent on the general action of God's creative effort, NIODA projects attempt to conceive of ways in which we may understand that creative effort in instances of special divine action neither contradict God's general action in the world as described by the natural sciences nor limits God to being a mere preserver of pre-determined laws.

As they have been presented above, however, continual creation theology and NIODA theory invite further application because they have merely established the possibility of divine action and have not yet addressed concrete events of special divine action. That is, they have sought to give an intelligible understanding to the question of how God can act in history, but the question of whether God really does act in history is a further question. In the context of Christian theology, a central event of God's special action in the world is the self-revelation of God in the resurrection of Jesus Christ. ${ }^{30}$

\section{Resurrection, FINLON, and transformation ex vetere}

The question of the reality of Christ's resurrection may be asked in two senses. In the first sense, the question may be asked as to whether or not it is possible that the resurrection of Christ is a historical fact. This is not a question that can be answered by scientific inquiry, for science is fundamentally inductive. That is to say, scientists must obey the somewhat redundant

\footnotetext{
${ }^{29}$ Russell's version of this theory can be found in Cosmology, chapter 5. Arthur Peacocke also mentions the connection between the subatomic and the macroscopic levels of the world as a possible locus for God's interaction in the world in, for example, chapter 9 of Theology for a Scientific Age: Being and Becoming - Natural, Divine, and Human (Minneapolis: Fortress Press, 1993): 135-188. John Polkinghorne outlines additional perspectives in "The Metaphysics of Divine Action," Chaos and Complexity: Scientific Perspectives on Divine Action, eds. Robert Russell, Nancey Murphy, and Arthur Peacocke (Vatican City State: Vatican Observatory Publications, 1995): 147156. A critique of the distinction between general and special divine action can be found in Niels Henrick Gregersen's "Special Divine Action and the Quilt of Laws: Why the Distinction between Special and General Divine Action Cannot be Maintained," in Scientific Perspectives on Divine Action: Twenty Years of Challenge and Progress, eds. Robert Russell, Nancey Murphy, and William Stoeger (Vatican City State: Vatican Observatory Publications, 2008), 179-200.

${ }^{30}$ One could apply these theories to other instances of special divine action; however, it is important to begin with the resurrection because as St. Paul writes, if Christ has not been raised from the dead then faith and preaching are in vain (1 Cor. 15:14). On a similar note, Russell states that examining the resurrection is necessary as a 'worst case' scenario "which makes Christianity the most vulnerable to its atheistic critics," Cosmology, 229.
} 
rule that "if it's true, then it must be possible,"31 and therefore hold to Paul's logic that resurrection must be possible if, indeed, Christ was resurrected (1 Cor. 15:12-22). Without data by which to ascertain the scientific truth of the Resurrection, scientists cannot establish the possibility or impossibility of the historical facticity of Christ's resurrection. In this sense, the question of the reality of the Resurrection remains a question of faith. Scientists of faith may, however, explore questions of the reality of the Resurrection in a second sense, where questions about the reality of Christ's resurrection seek an intelligibility of the Resurrection as a special action of God.

The reality of the Resurrection has been a theological, philosophical, scientific, and common-sense problem since Christ appeared to the Apostles in the upper room, but these problems take a particular form when one approaches them from the NIODA context. One of the major scientific questions asks how Christ can be raised from the dead without violating the laws of nature, for biology does not seem to have room within its laws for resurrection. One approach is to treat the Resurrection as an example of a "first instance of a new law of nature" (FINLON). ${ }^{32}$ This approach realizes that in the course of history, there is the possibility that a particular law is enacted for the first time. Biological laws, for example, could not have been enacted before the emergence of life systems. In this way, the resurrection of Christ may be seen as the "first instance of a new law of the new creation." 33

John Polkinghorne advocates that one of the premises of the law of new creation is the transformation of the universe ex vetere. If we accept that the resurrection of the dead is possible, then various problems arise related to the continuity between the old creation, which has died, and the new, resurrected creation. ${ }^{34}$ Polkinghorne argues that "the new creation arises ex vetere, as the redeemed transformation of the old creation, and not as a second, totally new, creation ex nihilo." 35 The premise of transformation ex vetere does not rely on the necessity of resurrected bodies to be raised as a second life of the same collection of atoms that once constituted a person, which is already an impossibly flawed concept given the constant process of change that human bodies undergo throughout their lives. Rather, it claims that our souls exist as information-bearing patterns "in which the matter of our bodies at any one time is organized." 36

\footnotetext{
${ }^{31}$ Cf. Ted Peters, "Robert John Russell's Contribution to the Theology and Science Dialogue," in God's Action in Nature's World: Essays in Honour of Robert John Russell, Ted Peters and Nathan Hallanger, eds. (Aldershot: Ashgate Publishing Company, 2006), $13 \mathrm{f}$.

${ }^{32}$ Cf. Russell, Cosmology, 309.

${ }^{33}$ Ibid., 310.

${ }^{34}$ Ted Peters illustrates four such problems: "(1) the place of the body (sōma), especially the flesh (sarx), in the resurrection; (2) the role divine power plays in raising the dead; (3) the problem of individual identity when discerning the continuity and discontinuity between what dies and what is raised; and (4) the problem of chain consumption - that is, the problem of identifying just which physical elements, if any, belong inextricably to an individual body," "Resurrection: The Conceptual Challenge," in Resurrection: Theological and Scientific Assessments, eds. Ted Peters, Robert John Russell, and Michael Welker (Grand Rapids: William B. Eerdmans Publishing Company, 2002), 298.

35 John Polkinghorne, "Eschatological Credibility: Emergent and Teleological Processes," Resurrection: Theological and Scientific Assessments, 50.

${ }^{36}$ Ibid., 51.
} 
These patterns are preserved in God's memory, and it is according to these patterns that eschatologically resurrected bodies are newly created.

The application of divine action to the special case of the Resurrection grapples not only with the possibility of divine special action but also with the reality of that action as it pertains to the Christian faith. Through the notions of FINLON and transformation ex vetere, scientisttheologians have started to address God's special action in the event of the resurrection of Jesus Christ from a NIODA perspective. This research advances the reconciliation of the canons of scientific inquiry with those of theology and thus serves as an excellent step towards a contemporary integrated cosmology. However, theories of divine action alone cannot fully close the divide between the cosmology of the natural sciences and that of theology. Theories of divine action work to address two concerns: (1) the possibility of God's ongoing action in creating and preserving the continually unfolding order of the cosmos, and (2) the application of these theories in understanding particular realities, like the resurrection of Christ. But the flattening process in cosmology was not brought about initially because the natural sciences determined that God and religion were incompatible with their theories of the natural world. Rather, the primary cause of the divorce between these two fields was dissatisfaction with the pre-modern moral order, the work of Reform, and the resulting formulation of metaphysical frameworks which sought to preserve the notion of God by relegating the realm of religion to the noumenal world.

If, then, cosmology was significantly flattened due to a new understanding of the world in which human meaning was no longer seen as an inherent feature in the fabric of the cosmos, then it does not seem likely that cosmology can be re-integrated without establishing the connection between human meaning and the order of the cosmos. In other words, it is not sufficient to ask questions related to the possibility or even the reality of God's action in the world, but rather, there is also the necessity to ask further questions of how that reality orders the cosmos in a humanly meaningful way. These questions will involve the realm of ethics but will also exceed purely ethical categories. ${ }^{37}$ Ernst Conradie asks several pertinent questions in which one can see the connection between the type of cosmology demanded by the Resurrection and the realm of ethics:

How can this hope address the Nietzschean suspicion that any hope for life after death constitutes a form of escapism? Can the hope for the resurrection of the dead remain true to this earth? How can we avoid the trap (that Jesus warned the Sadducees about in Matt. 22:29) of merely speculating about a virtual reality beyond the realm of this world? How

\footnotetext{
${ }^{37}$ Joseph Ratzinger makes the point that eschatology and the Resurrection revolve around the central theme of Jesus' proclamation of the Kingdom of God. This kingdom has a "decidedly ethical character" (quoting J. Schmid, Das Evangelium nach Markus, 2nd ed. [Regensburg, 1950], 28) and finds "expression in ethical categories," but nevertheless remains "pure gift, something sheerly received." In the same way, we might say that an integrated cosmology will unquestionably have a particularly ethical character; however, it will never be able to be fully reduced to ethics. See Joseph Ratzinger, Eschatology: Death and Eternal Life, trans. Michael Waldstein, ed. Aidan Nichols (Washington, D.C.: The Catholic University of America Press, 1988), 30-31.
} 
can a 'realistic eschatology' help us to understand this earthly reality better in order to take up our responsibilities here on earth? ${ }^{38}$

While the application of divine action theories to the Resurrection has the ability to raise such questions, I do not believe that it is fully within their capacity to respond to them. This is because the attempt to understand the reality of God's action in the world necessarily leads to the question of God's presence in the world. For example, beginning with the notion of creation ex vetere, John Polkinghorne writes the following:

The new creation represents the transformation of that universe when it enters freely into a new and closer relationship with its Creator, so that it becomes a totally sacramental world, suffused with the divine presence. Its process can be free from suffering, for it is conceivable that the divinely ordained laws of nature appropriate to a world making itself through its own evolving history should give way to a differently constituted form of 'matter,' appropriate to a universe 'freely returned' from independence to an existence of integration with its Creator. ${ }^{39}$

In other words, the act of God's new creation cannot be understood as what we might call a 'second deism' where God returns to the abandoned universe, acts in the person of Jesus, and then departs again. Rather, the promise of the new creation is also the promise of God's abiding presence with us. This promise has been inaugurated by Jesus, who is Immanuel-'God with us.' Therefore, with questions regarding the possibility and the reality of God's action in the world, the answers provided by divine action theories raise the further question of how we related to this action. If God does not merely act but abides with us in some manner, then we must account for our relationship with this presence and what this relationship implies about the humanly meaningful nature of the cosmic order.

\section{Towards an Integrated Cosmology by Way of a Theory of Divine Presence and the Doctrine of the Ascension}

The Christian understanding of divine presence in the world is complicated and paradoxical. As the early Christian Church developed its understanding of the event of Jesus' resurrection, it became increasingly concerned with two conflicting notions. On one hand, they believed in the presence of God at work in the newly created Kingdom inaugurated by Christ, but on the other hand they experienced a sense of God's absence in the world as well. The Temple was destroyed, the apocalypse had not come, and Christians were left to give an account of their faith in light of these seemingly contradictory experiences. These two experiences-the profound presence of God in the world through Christ and the disturbing absence of Christ-soon gave rise to reflection not only on the event of the Resurrection, but also the Ascension.

\footnotetext{
${ }^{38}$ Ernst Conradie, "Resurrection, Finitude, and Ecology," in Resurrection: Theological and Scientific Assessments, 287.

39 John Polkinghorne, The Faith of a Physicist: Reflections of a Bottom-Up Thinker (Princeton: Princeton University Press, 1994), 167.
} 
The doctrine of Ascension in the flesh is clearly difficult for the post-Copernican world; it is quite simply not possible for us to imagine the risen Christ merely floating off to a heaven which lies above the clouds. Here, we would like to say that contemporary scientific cosmology has replaced the earlier (or, perhaps, 'religious') cosmological worldview. These difficulties with the Ascension will clearly need to be addressed in the formation of a contemporary integrated cosmology. But the scandal of the doctrine of Ascension in the flesh is both older and deeper than this recent tiff with modern science, and it will also be necessary to return to these older concerns in order to treat the subject in its original context.

The notion of the Ascension has scandalized the Christian community at least as far back as the writing of John's gospel. In his book, Ascension and Ecclesia, Douglas Farrow points out how the Ascension is portrayed as a scandal even greater than the Eucharist: "Addressing the dispute that broke out among his followers over the seemingly coarse and foolish notion of eating his flesh and drinking his blood, Jesus asks: 'Does this offend you? What if you see the Son of Man ascend to where he was before!" 40 As great of a mystery (and as great of an offense) as the Eucharist was, it appears that the Johannine narrative recognizes the Ascension as an even greater mystery and, likewise, offense. Thus, the real scandal of the doctrine of Ascension in the flesh, as it was originally articulated by Irenaeus of Lyons, is that it recognizes a cosmic significance of both the person of Jesus as well as the Church.

Regarding the cosmic significance of this doctrine, Farrow articulates how Irenaeus' position-including the doctrine of Ascension in the flesh-maintains that the Church is situated squarely in a paradoxical position between not one but two histories. Farrow describes these two histories as follows:

In biblical terms the ascension involves a real departure of Jesus of Nazareth. That is the basis on which we find ourselves compelled to speak of two histories rather than one. Covenant history and world history have divided in this departure, for in and with Jesus the former has already reached its goal. In the resulting gap a place has opened up for the eucharistic community as a genuinely new entity within the world history, albeit a peculiar one with its own peculiar view of the way things are. ${ }^{41}$

In other words, there is a particular history in which the person of Jesus Christ is present with us. But in another distinct history, the Christ whom the Church waits and longs for to return in glory on the last day has gone where we cannot follow.

But although Irenaeus' position on the doctrine of the Ascension requires two histories, we must be careful not to let this distinction degrade into one of two categorical mistakes. The first mistake is to reduce the simultaneous presence and absence of Christ to a distinction between two worlds: the nominal and the phenomenal. In light of the prevalence of this mistake and its easy confusion with the language of 'two histories,' it may well be necessary to move

\footnotetext{
${ }^{40}$ Douglas Farrow, Ascension and Ecclesia (Grand Rapids: William B. Eerdmans, 1999), 38. Farrow is referencing John 6:61-62.

${ }^{41}$ Ibid., 40.
} 
beyond Irenaeus' formulation. ${ }^{42}$ The key insight from Irenaeus that must be maintained is that there exists a real and paradoxical simultaneity of both the presence and absence of Jesus Christ that is upheld cosmically through the event of the Eucharist and, therefore, within the Church. The second mistake appears much earlier in history as the desire to answer the question of presence and absence by posing that the historical Jesus is now absent although the divine Christ is still with us. This division is rejected by the doctrine of Ascension in the flesh. According to this doctrine, there is only one person, Jesus Christ, and that person is both present and absent to us. It is for this reason that we must speak of the simultaneity of the presence and absence of Jesus Christ.

The true difficulty of the doctrine of the Ascension, then, is not that it upholds a scientifically impossible picture in which Jesus goes floating off into the clouds. Rather, the Ascension defies straightforward comprehension precisely because it points to the mysterious absence of Christ-it points to the fact that we do not know where he has gone. ${ }^{43}$ We may say that Christ sits at the right hand of the Father, but that is a theological notion and not a spatiotemporal one. However, the fact that Jesus' ascension insists upon his absence does not deny his simultaneous presence. Indeed, Christian faith maintains that it is this same person Jesus Christ who reorganizes our cosmos. In the same light that re-creation ex vetere was spoken of above, we may say that Christ's 'reorganization' of the cosmos is not "something that works itself out within the terms of our own spatio-temporal processes, for ours is the very space and time that requires reorganization. Yet it is a spatio-temporal process, since it is we ourselves who are made the objects of it and, with Jesus, its participants and beneficiaries." ${ }^{\prime 4}$

Here, we see where a theory of divine presence connects back to the scientific advances related to the theory of divine action while at the same time going beyond it. Christ's ascension remains in continuity with his resurrection in the sense that his departure does not exclude the first instantiation of a new law of nature that occurred in his act of new creation ex vetere. However, a discussion of divine presence in the world also insists that there is a particular manner in which this new creation is not only a singular historical fact of the resurrection but also an enduring reality within the cosmos. Within the Christian faith, however, that reality of presence does not manifest itself in what we have called God's general action in the world but rather in God's special, non-interventionist creation ex vetere that takes place in the event of the Eucharist. The Eucharist, then, is a truly cosmic event and not a mere noumenal or subjective

\footnotetext{
${ }^{42}$ Strangely, Farrow does not give this thought any attention. While he makes note of Kant's distinction between noumena and phenomena (Ascension and Ecclesia, 168ff.), his concern is to reject the result of this distinction by which ethics becomes concerned with what humanity can do for itself rather than what God does for humanity. This unfortunate lack of clarification between Irenaeus' 'two histories' language and the Kantian noumenal/phenomenal distinction is, in my opinion, a major oversight that requires further attention.

${ }^{43}$ Farrow writes: "we cannot place him, spatially or temporally or materially or spiritually, with respect to ourselves; that he is not above us or ahead of us or alongside us or within us, even if each of these metaphors has something helpful to say about his actual relation to us. [The Ascension] is disturbing because it challenges the assumption that to talk about a human being who cannot be so placed is meaningless, and because it implies that every attempt to define him as something other than a human being is really an act of violence designed to force him to yield his meaning on our terms," Ascension and Ecclesia, 267.

${ }^{44}$ Ibid, 264.
} 
conception purely within the human mind. The Eucharist bears human meaning, but this meaning mediates a real presence of God in the world.

\section{Conclusion}

It is only within this final movement from divine action to divine presence that we can begin to formulate a truly integrated cosmology. In contrast to the 'subtraction stories' of modernity, if the flattening of cosmology was brought about in the movement from a 'cosmos' to a 'universe' in which human meaning was divorced from the fabric of the cosmos, then a contemporary integrated cosmology needs to re-conceive the place of human meaning within the cosmos. This new conception will need to continue the creative mutual exchange between the insights drawn from both science and theology, but it will also need to advance from a conversation about divine action to a conversation about divine presence. It will grapple not only with the doctrine of the Resurrection, but also with the doctrine of the Ascension. In doing so, it will necessarily be forced to confront the condition of human brokenness and longing in a world where the absence of its creator is a difficult reality, yet hope for the Parousia remains. Finally, an integrated cosmology will recognize both the reality of God's new creation in the Eucharistic celebration of the Church while at the same time recognizing the existence of the Church in a world which has not yet been perfected through, in, and with its eternal Creator. This recognition must always be an act of faith, but it is a solid faith upon which we may truly ground an authentic Christian life. 